\title{
PROGRAMME COMPETENCES FOR MANAGEMENT STUDENTS IN THE COVID-19 PANDEMIC
}

\author{
Gennadiy Karimov ${ }^{1}$, Ivan Karimov ${ }^{2}$, Marina Romaniukha ${ }^{3}$, \\ \& Liudmyla Sorokina ${ }^{4}$ \\ DSTU, Kamianske, Dniprobudivska st. 2 \\ 19karimov@ukr.net, ORCID 0000-0002-0208-2607 \\ 2ikarimov@ukr.net, ORCID 0000-0003-4145-9726 \\ 3romanuks@ukr.net, ORCID 0000-0001-7623-2690 \\ 4sludmila1906@gmail.com, ORCID 0000-0003-4875-2896
}

\begin{abstract}
The paper discusses programme competences of students majoring in the specialty 073 - Management in conditions of distance learning caused by the pandemic COVID-19. It analyses the influence of distance learning methods and techniques on the programme competences of managers. The paper studies the curriculum design of the first (bachelor's) degree course 073 - Management within the field of knowledge "Management and Administration" (07) at one of the typical higher education institutions in Ukraine in conditions of distance learning. The authors consider relevant components of the curriculum design. The analysis allowed the authors to identify which of the programme competences in the course design were made easier for the students to acquire due to pandemic-induced distance learning mode. The authors suggest a way to improve the curriculum design for the next year of study.
\end{abstract}

Keywords: distance learning; competences; higher education; students; management.

\section{INTRODUCTION}

\section{The research problem}

The COVID-19 pandemic has dramatically affected all spheres of society, including education. During the forced distance learning period a number of technical, psychological and methodological problems emerged.

Due to observed changes in the modern academic environment we are witnessing the enrichment of educational terminology reflecting the specific work mode we are forced to experience. Experts stress that it can not be labeled 'online learning', but rather emergency remote teaching (Iglesias et al., 2021) or emergency online teach- 
ing (Lorenza \& Carter, 2021), reflecting the unprecedented speed of change the COVID-19 pandemic caused in the teaching community. The terms represent both the urgent move from presence classes to an online blended mode and a sense of disruption among the teaching community and the learners (Lorenza \& Carter, 2021). Evidently, this partially unprepared mode of work presents feasible advantages for both participant groups of the learning process, saving travel time to the auditoria, opening up new opportunities for collaboration and production of ideas. However, the opportunities are somewhat balanced by new challenges for the academic community and the educational management, namely elaborating digital environments to serve online teaching and learning. Another challenge is to develop adequate attitude among faculty members towards distance teaching in order to ensure equal levels of knowledge and competences provided in both mode of study (Szopinski \& Bachnik, 2022).

The unprecedented speed of change leading to a shift in mode of work evidently increases the instructor's workload, demanding extra effort to present the learning content equal to the one developed in traditional classrooms (Iglesias-Pradas et al., 2021). The experts argue that for the students' learning effectiveness largely depends on their ICT competence, motivational factors and virtual competency factors, since all these factors combined positively impacts their learning and involvement (Amin et al., 2021).

There is a growing body of research confirming overall high academic performance of students in forced remote teaching mode (Iglesias-Pradas et al., 2021), with particular subject-specific cases where the learners benefited from the new challenges presented by the COVID-19 changed living environment. Namely, an interesting case in Poland demonstrates students of management and production management and engineering learning a new skill of creating complex websites based on CMS WordPress. Consequently, the change in the syllabus was found beneficial for the students and for the university program as well, as it allowed the faculty management to adapt curriculum to market needs and better equip modern graduates for competition on the job market (Krupcała, 2021).

Competence-wise, the main normative document regulating distance learning is the "Regulations on distance learning", approved by the order No. 466 of the Ministry of Education and Science of Ukraine of 25 April 2013. The document highlights a significant use of information and communication technologies (Polozhennya pro distancijne navchannya, 2015). All this calls for paying special attention to the issue of obtaining programme competences and relevant programme learning outcomes for university students at all levels. Thus, the problem of research is to identify in what ways the competence components of the curriculum for the Management course changed during the pandemic-induced learning period and to see the ways to improve the curriculum design. 


\section{PROGRAMME COMPETENCES IN DISTANCE LEARNING}

\subsection{Research methodology}

The theoretical basis of the study is formed by basic principles and provisions in the field of higher education of Ukraine. In the process of solving the tasks there were used historical-logical and systematic approaches, general and special methods, in particular: monographic and abstract-logical methods (in analysing the impact of distance learning on the programme competences of managers); methods of observation and generalization (in the analysis of the use of elements of distance learning); methods of system analysis and synthesis.

\subsection{Theoretical background}

Reference to modern psychological and pedagogical technologies strongly highlights the essence of distance learning and urges the educational management to take into account its special features (Karimov, Kuzmenko, \& Radchenko, 2020). The solution of these problems has forced to intensify certain programme competences of students, which are related to the use of information and communication technologies and skills of independent and team work. The acquisition of such competences is the result of achieving the following learning outcomes (learning objectives), according to the classification that is generally accepted in the international educational environment:

- in the cognitive (gnostic) area, according to B.S. Bloom (Bloom 1984) A pplying - the ability to use the studied material in new situations.

Evaluation - the ability to assess the importance of the material for a specific purpose.

- in the emotional (affective) sphere, according to W. Krathwohl (Krathwohl; Bloom, Masia 1964)

Perception. Characterizes the desire (motivation) of the student to receive the necessary information.

Responding. Concerns the active participation of the student in the educational process.

Organization and Conceptualization. It refers to the processes that individuals face, when it is necessary to combine different values, resolve conflicts between them and assimilate a specific system of values.

Characterization by a Value or Value Set. At this level, a person has developed a system of values that determines their consistent and predictable behaviour.

- in the psychomotor (activity) area (Krathwohl; Bloom, Masia 1964)

Reproduction of manipulations. Performing certain actions with instructions and practical skills.

Develop Precision. The ability to perform tasks with a small number of errors and do it more accurately without professional help.

As one can see, most of the points belong to the emotional (affective) or value-motivational aspect of educational goals, i.e. the perception of specifics and features of distance learning by the students. 
When it comes to educational goals and forecasted competences, it is worth addressing the documents developed within the TUNING project, defined by the working group itself as a "university driven project which aims to offer a concrete approach to implement the Bologna process at the level of higher education institutions and subject areas". Distinguishing between subject specific and generic competence, the Tuning team lists the following generic competences:

- instrumental competences: cognitive abilities, methodological abilities, technological abilities and linguistic abilities;

- interpersonal competences: individual abilities like social skills (social interaction and cooperation);

- systemic competences: abilities and skills concerning whole systems (combination of understanding, sensibility and knowledge; prior acquisition of instrumental and interpersonal competence required) (Tuning Educational Structures, 2007).

At present, the main proportion of university graduates students of the first (bachelor's) level of education. The bachelor's degree or its equivalent according to UNESCO (International Standard Classification of Education, 2013) corresponds to the sixth level of education to which the National Qualifications Framework puts forward a list of descriptors in four areas: Knowledge, Skills, Communication, Responsibility and Autonomy (Kabinet Ministriv Ukraïni, 2012). From the list of descriptors of the National Qualifications Framework, in our opinion, it is advisable to pay attention to the following:

\section{Communication}

- Communicating information, ideas, problems, solutions, personal experience and arguments to specialists and non-specialists

- Data collection, interpretation and application

\section{Responsibility and autonomy}

- Ability to take responsibility for developing and making decisions in unpredictable work and / or learning contexts

- Forming judgments that take into account social, scientific and ethical aspects

- Organization and management of professional development of individuals and groups

- Ability to continue learning with a significant degree of autonomy.

That is, the specifics of distance education activates, first of all, the communicative abilities, independence of decisions and responsibilities of students.

Taking into account the general list of descriptors of the National Qualifications Framework, which receive an additional positive impetus in the situation of distance learning, the following skills are highlighted for future managers according to the Standard of higher education for the first (bachelor's) level, specialty 073 - Management (Standart vishchoï osviti, 2018):

\section{Communication}

- Ability to effectively formulate a communication strategy. 
Autonomy and responsibility

- Management of complex actions or projects, responsibility for decision-making in unpredictable conditions.

- Responsibility for professional development of individuals and/or groups of individuals, ability to continue studying with a high level of autonomy.

\section{PROGRAMME COMPETENCES OF FUTURE MANAGERS}

From the list above in the conditions of distance learning we consider the following categories as key indicators for managers:

1 - developing communication strategy (Communication)

2 - responsibility for decisions in unpredictable conditions (Responsibility)

3 - the ability to learn with a high level of autonomy (Autonomy).

Tables 1 and 2 present the correspondence of these categories to the competences defined by the curriculum design for the course 073 - Management in the field of knowledge 07 - Management and Administration for the first (bachelor's) level of higher education (Kucher, Voronina \& Tarasenko, 2019) of Dniprovsky State Technical University. The correspondences defined by the National Standard (Standart vishchoï osviti, 2018) are marked as " +". The correspondences not defined by the Standard, but in our opinion present, are marked as "**. Table 1 discusses aspects of generic competences of future managers:

\section{Ta b l e 1. Correspondence of categories to the generic competences of future managers}

\begin{tabular}{l} 
Competences \\
1. the ability to exercise their rights and responsibilities as a member of \\
society, to be aware of the values of civil (democratic) society and the \\
need for its sustainable development, the rule of law, human and civil \\
rights and freedoms in Ukraine; \\
2. the ability to preserve and promote moral, cultural, scientific values \\
and build upon the achievements of society based on understanding the \\
history and patterns of development of the subject area, its place in the \\
general system of knowledge about nature and society as well as in the \\
development of society, machinery and technology; use various kinds \\
and forms of movement for active recreation and healthy living; \\
3. capacity for abstract thought, analysis, synthesis; \\
\hline 4. ability to apply knowledge in practical situations \\
\hline 5. domain knowledge and professional expertise
\end{tabular}


6. the ability to communicate in the national language both orally and in written form;

7. the ability to communicate in the foreign language;

8. skills of using ICT-technologies;

9. the ability to learn and acquire modern knowledge;

10. aptitude to hold research at the appropriate level;

11. ability to adapt and act in a new situation;

12. potential to generate new ideas (creativity);

13. appreciating and respecting diversity and multiculturality;

14. ability to work in an international context;

15. ability to act out of ethical considerations (motives);

16. ability to take initiative, responsibility and skills for safe activities in accordance with the future profile of work, industry norms and rules, as well as the required level of individual and collective safety in emergencies (defined by educational institution).

S o u r c e: own work based on (Standart vishchoï osviti, 2018;

Kucher, Voronina, \& Tarasenko, 2019).

Table 2 discusses precisely aspects of specific competences of future managers:

Ta ble 2. Correspondence of categories to the specific competences of future managers

\section{Competences}

Categories

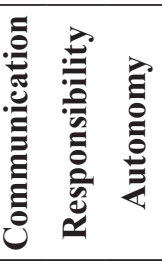

1. ability to identify and describe the characteristics of the organization;

2. the ability to assess the results of the organization and correlate them with factors of external and internal environment;

3. ability to determine the prospects for the development of the organization;

4. ability to determine the functional areas of the organization and the relationships between them;

5. ability to manage the organization and its departments through the implementation of managerial functions;

6. the ability to act in a socially responsible conscious way;

7. ability to choose and use modern management tools;

8. ability to plan the activities of the organization and manage time; 
9. the ability to work in a team and establish interpersonal interaction in * solving professional problems;

10. the ability to assess the work performed to ensure its quality and motivate the staff of the organization;

11. ability to create and organize effective communication in the manage- $*_{+}$ rial process;

12. ability to analyse and structure the problems of the organization to develop efficient solutions;

13. understand the principles and norms of law and use them in professional activities;

14. understand the principles of psychology and apply them in professional activities;

15. ability to form and demonstrate leadership qualities and behavioural * skills.

S o u r c e: own work based on (Standart vishchoï osviti, 2018;

Kucher, Voronina, \& Tarasenko, 2019).

The competences that did not receive any mark of compliance with the key categories of successful distance learning are considered to have been negatively affected by distance learning tools and methods. These competences are not discussed further. Correspondence of other competences to learning outcomes of future managers majoring in Management is given in Table 3.

Tab le 3. Compliance of future managers' competences to learning outcomes

\section{Learning outcomes}

Competences

general specific

1. know one's rights and responsibilities as a member of society, be aware of the values of civil society, the rule of law, human and civil rights and freedoms in Ukraine;

2. preserve moral, cultural, scientific values and promote the achievements of society, use different types and forms of physical activity in order to lead a healthy lifestyle;

3. demonstrate knowledge of the theory, methods and functions of $9 \quad 3,5$ management, modern leadership concepts;

4. demonstrate skills of problem identification and justifying man- $11,12 \quad 10$ agerial decisions;

5. describe the content of the functional areas of the organization;

6. to show skills of search, storage and the analysis of information, calculation of indicators in order to justify administrative decisions;

7. identify organizational design skills; 


\begin{tabular}{lcc}
\hline $\begin{array}{l}\text { 8. apply management techniques to ensure the effective operation } \\
\text { of the organization; }\end{array}$ & $2,5,6,7,11$ \\
\hline 9. demonstrate collaboration, leadership, teamwork skills; & $5,13,15$ \\
\hline $\begin{array}{l}\text { 10. have the skills to justify effective tools to motivate the organiza- } \\
\text { tion's staff; }\end{array}$ & 11 & 7 \\
\hline $\begin{array}{l}\text { 11. demonstrate skills of situation analysis and communication in } \\
\text { various areas of the organization; }\end{array}$ & 8 & 11 \\
\hline $\begin{array}{l}\text { 12. assess the legal, social and economic consequences of the or- } \\
\text { ganization's activity; }\end{array}$ & $6,7,14,15$ \\
\hline $\begin{array}{l}\text { 13. the ability to communicate in the national and foreign language } \\
\text { both orally and in written form; }\end{array}$ & 11,14 \\
\hline $\begin{array}{l}\text { 14. identify the causes of stress, adapt themselves and team mem- } \\
\text { bers to the stressful situation, find ways to neutralize it; }\end{array}$ & 15 \\
\hline $\begin{array}{l}\text { 15. demonstrate the ability to act in a socially responsible and civic- } \\
\text { aware way on the basis of ethical considerations (motives), re- } \\
\text { spect for diversity and multiculturalism; }\end{array}$ & $6,14,15$ \\
\hline $\begin{array}{l}\text { 16. demonstrate skills of independent work, flexible thinking, } \\
\text { openness to new knowledge, critical thinking skills and self- } \\
\text { criticism; }\end{array}$ & \\
\hline
\end{tabular}

17. perform research individually and / or in a group under the guidance of a leader;

18. demonstrate skills for safe activity in accordance with the future 16 profile of work, industry norms and rules, as well as the required level of individual and collective level of safety in emergencies (defined by the educational institution).

S o u r c e: own work based on (Standart vishchoï osviti, 2018; Kucher, Voronina, \& Tarasenko, 2019).

Given the predicted learning outcomes, we believe that generic programme competences No. 1, 6, 7, 12, 13, 14, 16 (see Table 1) and special programme competences No. 2, 3, 5, 7, 13, 14, 15 (see Table 2) are acquired by student managers regardless of the form of training. In other words, the introduction of distance learning did not affect the acquisition of these competences. The remainder of the list of competences for student managers during the forced distance learning period has strengthened its applied component. Thus, it is possible to distinguish three groups of competences according to the amount of influence they experienced during forced distance learning period:

- Negative influence

- Lack of significant impact

- Positive impact

Accordingly, the third group of competences presents the biggest interest for further consideration. 


\section{COMPONENTS OF THE CURRICULUM FOR STUDENT MANAGERS}

Consequently, the group of programme competences that have been positively affected by the intensification of distance learning includes four competences from the list of generic competences and four from the list of specific programme competences of the curriculum for the course 073 "Management" for the first (bachelor's) level. The correspondence of programme competences and learning outcomes to the components of the curriculum is presented in Table 4. It enumerates those specific learning outcomes, which, in our opinion, have had a positive impact from distance learning.

Tab le 4. Compliance of future managers' programme competences and learning outcomes to the components of the curriculum

\begin{tabular}{|c|c|c|c|}
\hline Competences & $\begin{array}{l}\text { Components } \\
\text { of the } \\
\text { curriculum }\end{array}$ & Learning outcomes & $\begin{array}{l}\text { Components of } \\
\text { the curriculum }\end{array}$ \\
\hline \multicolumn{4}{|c|}{ Generic competences } \\
\hline \multirow[t]{2}{*}{$\begin{array}{l}\text { 8. Skills } \\
\text { of using } \\
\text { information } \\
\text { and } \\
\text { communication } \\
\text { technologies; }\end{array}$} & $\begin{array}{l}\text { GS 1.6, PS } \\
2.16, \text { PS } \\
2.17, \text { ES } 1.8\end{array}$ & $\begin{array}{l}\text { 6. to show skills of search, storage } \\
\text { and the analysis of information, } \\
\text { calculation of indicators; }\end{array}$ & $\begin{array}{l}\text { GS } 1.5, \text { GS } 1.6, \\
\text { GS } 1.7, \text { PS } 2.2, \\
\text { PS } 2.2 .1, \text { PS } 2.5 \text {, } \\
\text { PS } 2.5 .1, \text { PS } 2.6 \text {, } \\
\text { PS } 2.7, \text { PS } 2.8, \text { PS } \\
2.12, \text { PS } 2.15, \text { PS } \\
2.17, \text { ES } 1.5, \text { ES } \\
1.6, \text { ES } 1.8, \text { ES } \\
1.10\end{array}$ \\
\hline & & $\begin{array}{l}\text { 11. demonstrate skills of situation } \\
\text { analysis and communication in } \\
\text { various areas of the organization; }\end{array}$ & $\begin{array}{l}\text { GS } 1.6, \text { PS } 2.5 .4, \\
\text { PS } 2.8, \text { PS } 2.11, \\
\text { PS } 2.16, \text { PS } 2.17\end{array}$ \\
\hline $\begin{array}{l}\text { 9. ability to } \\
\text { learn and } \\
\text { acquire } \\
\text { modern } \\
\text { knowledge; }\end{array}$ & $\begin{array}{l}\text { GS 1.7, PS } \\
2.5, \text { PS 2.5.1 }\end{array}$ & $\begin{array}{l}\text { 15. demonstrate skills of indepen- } \\
\text { dent work, flexible thinking, open- } \\
\text { ness to new knowledge, critical } \\
\text { thinking skills and self-criticism; }\end{array}$ & $\begin{array}{l}\text { PS } 2.5, \text { PS } 2.5 .3, \\
\text { PS 2.15, PS } 2.16 \text {, } \\
\text { PS 2.17, ES 1.5, } \\
\text { ES } 1.6\end{array}$ \\
\hline \multirow[t]{2}{*}{$\begin{array}{l}\text { 11. ability } \\
\text { to adapt and } \\
\text { act in a new } \\
\text { situation; }\end{array}$} & $\begin{array}{l}\text { PS 2.5, PS } \\
2.5 .5, \text { PS } \\
2.5 .7, \text { ES } 1.2\end{array}$ & $\begin{array}{l}\text { 4. demonstrate skills of problem } \\
\text { identification and justifying mana- } \\
\text { gerial decisions; }\end{array}$ & $\begin{array}{l}\text { PS } 2.3, \text { PS } 2.5, \text { PS } \\
2.5 .4, \text { PS } 2.5 .6, \\
\text { PS } 2.5 .8, \text { PS } 2.7, \\
\text { PS } 2.10, \text { PS } 2.15 \text {, } \\
\text { PS } 2.17, \text { ES } 1.5 \text {, } 1.7, \text { ES } 1.10\end{array}$ \\
\hline & & $\begin{array}{l}\text { 16. demonstrate skills of independ- } \\
\text { ent work, flexible thinking, open- } \\
\text { ness to new knowledge, critical } \\
\text { thinking skills and self-criticism; }\end{array}$ & $\begin{array}{l}\text { PS } 2.5, \text { PS } 2.5 .3 \text {, } \\
\text { PS } 2.15, \text { PS } 2.16 \text {, } \\
\text { PS } 2.17, \text { ES } 1.5, \\
\text { ES } 1.6\end{array}$ \\
\hline
\end{tabular}




\begin{tabular}{|c|c|c|c|}
\hline $\begin{array}{l}\text { 15. ability } \\
\text { to act on the } \\
\text { basis of ethical } \\
\text { considerations } \\
\text { (motives); }\end{array}$ & $\begin{array}{l}\text { GS 1.1, GS } \\
1.3, \text { PS 2.1, } \\
\text { ES 1.3, ES } \\
1.4\end{array}$ & $\begin{array}{l}\text { 14. identify the causes of stress, } \\
\text { adapt themselves and team mem- } \\
\text { bers to the stressful situation, find } \\
\text { ways to neutralize it; }\end{array}$ & $\begin{array}{l}\text { GS } 1.8, \text { PS } 2.5, \\
\text { PS } 2.5 .3, \text { PS } \\
2.5 .5, \text { PS } 2.17, \text { ES } \\
1.2\end{array}$ \\
\hline \multicolumn{4}{|c|}{ Specific competences } \\
\hline $\begin{array}{l}6 . \text { the ability } \\
\text { to act in } \\
\text { a socially } \\
\text { responsible } \\
\text { conscious way; }\end{array}$ & $\begin{array}{l}\mathrm{ES} 1.3, \mathrm{ES} \\
1.4\end{array}$ & $\begin{array}{l}\text { 15. demonstrate the ability to } \\
\text { act in a socially responsible and } \\
\text { civic-aware way on the basis of } \\
\text { ethical considerations (motives); }\end{array}$ & $\begin{array}{l}\text { GS 1.1, GS 1.3, } \\
\text { PS 2.1, PS 2.17, } \\
\text { ES 1.3, ES 1.4, } \\
\text { ES 1.9 }\end{array}$ \\
\hline $\begin{array}{l}\text { 9. ability to } \\
\text { work in a team } \\
\text { and establish } \\
\text { interpersonal } \\
\text { interaction } \\
\text { while solving } \\
\text { professional } \\
\text { problems; }\end{array}$ & $\begin{array}{l}\text { PS 2.5, PS } \\
2.5 .5, \text { ES } 1.4\end{array}$ & $\begin{array}{l}\text { 16. perform research individually } \\
\text { and/or in a group; }\end{array}$ & $\begin{array}{l}\text { PS } 2.5, \text { PS } 2.5 .5, \\
\text { PS } 2.7, \text { PS } 2.15, \\
\text { PS } 2.16, \text { PS } 2.17, \\
\text { ES } 1.5, \text { ES } 1.6, \\
\text { ES } 1.8, \text { ES } 1.10\end{array}$ \\
\hline $\begin{array}{l}\text { 10. the ability } \\
\text { to evaluate } \\
\text { the work } \\
\text { performed; }\end{array}$ & $\begin{array}{l}\text { PS } 2.5, \text { PS } \\
2.5 .4, \text { PS } \\
2.5 .6, \text { PS } \\
2.12, \text { PS } \\
2.15, \text { PS } \\
2.17, \text { ES } 1.9\end{array}$ & $\begin{array}{l}\text { 4. demonstrate skills of problem } \\
\text { identification and justifying mana- } \\
\text { gerial decisions; }\end{array}$ & $\begin{array}{l}\text { PS } 2.3, \text { PS } 2.5, \text { PS } \\
2.5 .4, \text { PS } 2.5 .6, \\
\text { PS 2.5.8, PS 2.7, } \\
\text { PS 2.10, PS 2.15, } \\
\text { PS 2.17, ES 1.5, } \\
\text { ES 1.7, ES } 1.10\end{array}$ \\
\hline $\begin{array}{l}\text { 11. ability to } \\
\text { create and } \\
\text { organize } \\
\text { effective } \\
\text { communication } \\
\text { in the } \\
\text { managerial } \\
\text { process. }\end{array}$ & $\begin{array}{l}\text { PS 2.5, PS } \\
2.5 .5, \text { PS } \\
2.5 .6, \text { PS } \\
2.11, \text { PS } 2.17\end{array}$ & $\begin{array}{l}\text { 11. demonstrate skills of situation } \\
\text { analysis and communication in } \\
\text { various areas of the organization. }\end{array}$ & $\begin{array}{l}\text { GS } 1.6, \text { PS } 2.5, \\
\text { PS 2.5.4, PS 2.8, } \\
\text { PS 2.11, PS 2.16, } \\
\text { PS } 2.17\end{array}$ \\
\hline
\end{tabular}

Note s: GS - general subjects, PS - professional subjects, ES - elective subjects S o u r c e: own work based on (Kucher, Voronina, \& Tarasenko, 2019).

Analysing the coincidences of disciplines that provide the acquisition of programme competences and relevant learning outcomes, as well as syllabi of relevant disciplines (Information portal of Dniprovsky State Technical University) we compiled a list of disciplines that demonstrated an increased applied component of competences for students majoring in Management during the distance learning period. The final list is presented in Table 5 . 
Table 5. The disciplines, promoting the acquisition of programme competences by future managers

\begin{tabular}{|c|c|}
\hline Programme competences & Disciplines \\
\hline $\begin{array}{l}\text { Skills of using information and } \\
\text { communication technologies }\end{array}$ & $\begin{array}{l}\text { Information systems and technologies } \\
\text { Models and methods of optimization }\end{array}$ \\
\hline Ability to learn and acquire modern knowledge & Management and administration \\
\hline Ability to adapt and act in a new situation & $\begin{array}{l}\text { Management and administration } \\
\text { Psychology }\end{array}$ \\
\hline $\begin{array}{l}\text { Ability to act on the basis of ethical } \\
\text { considerations (motives) }\end{array}$ & $\begin{array}{l}\text { Management and administration } \\
\text { Psychology } \\
\text { Sociology }\end{array}$ \\
\hline $\begin{array}{l}\text { The ability to act in a socially responsible } \\
\text { conscious way }\end{array}$ & $\begin{array}{l}\text { Philosophy } \\
\text { Sociology }\end{array}$ \\
\hline $\begin{array}{l}\text { Ability to work in a team and establish } \\
\text { interpersonal interaction in solving } \\
\text { professional problems }\end{array}$ & $\begin{array}{l}\text { Management and administration } \\
\text { Sociology } \\
\text { Introduction to scientific research }\end{array}$ \\
\hline Ability to evaluate the work performed & $\begin{array}{l}\text { Management and administration } \\
\text { Introduction to scientific research }\end{array}$ \\
\hline $\begin{array}{l}\text { Ability to support the managerial process } \\
\text { with effective communicative situations }\end{array}$ & $\begin{array}{l}\text { Management and administration } \\
\text { Information systems and technologies }\end{array}$ \\
\hline
\end{tabular}

S ource: Own work.

Thus, the selected disciplines enrich the curriculum of the Management course by including the methods and techniques of distance learning. It should be noted that the course Management and Administration, primarily takes into account the studying module Self-Management.

Since the Law of Ukraine "On Higher Education" defines the distance form of education as "individualized process of education” (Zakon Ukraïni „Pro viŝu osvitu”, 2021), it is advisable to consider a wider implementation of the asynchronous mode in the educational process. In particular, the Regulation on distance learning (Polozhennya pro distancijne navchannya, 2015) provides for the use of asynchronous mode for obtaining training materials, communication between subjects, lectures, consultations, seminars, practical classes, which include practical (assessment) work, business games, project implementation in groups, etc. In our opinion, when using distance learning technologies in training future managers attention should be focused on the following main elements recommended by the Ministry of Education and Science of Ukraine:

- digital tools for multilevel individual and group tasks (to compile a report, a multimedia presentation, a project, a video, etc.) on the material being studied;

- testing tools for formative and summative assessment with questions selected randomly from the test database for each student, as well as mixed answer options;

- tools for the teacher to assess the interaction and communication between students through a chat, forum, survey, questionnaire, etc.; 
- the tools for tasks that require detailed, creative solutions (for example, cases) (Rekomendaciï sodo organizaciï, 2020).

However, the practical mechanism for introducing such elements into the work programmes of full-time education needs further elaboration.

\section{CONCLUSION}

Consequently, it is advisable for the educational management of the university to reconsider the structure of the curriculum and to enrich the specific curriculum of the course Management by instruments and tools of distance and online learning, since they have proved efficient for the disciplines mentioned in Table 5 and help shape future managers' competences. This process will go in stages in accordance with the Regulations on the organization of the educational process at the Dniprovsky State Technical University (Gulayev, Peremitko, \& Hlushchenko et al., 2017):

- the Scientific and Methodological Council of the university receives from the Scientific and Methodological Commission of the Faculty of Management, Economics, Sociology and Philology the list of disciplines, enriched by distance learning instruments and tools, and grants the right to introduce them on a regular or more flexible basis;

- the scientific and methodological commission of the Faculty delegates to the relevant departments to adjust the syllabi of specific academic disciplines for the next academic year.

We support the view that COVID-19 should be seen not so much as a temporary solution before the academic community switches back to presence teaching mode, but more so a feasible move towards the improvement of digital teaching skills among professors and educational management (Iglesias-Pradas, 2021).

Thus, the university as a whole and individual professors thrive from ample opportunities to develop and balance teaching methods that enhance the practical acquisition of programme competences by the students.

\section{REFERENCES}

A m in, I., You sa f, A., Wa li a, S., \& B a sh i r, M. (2021). What Shapes E-Learning Effectiveness among Tourism Education Students? An Empirical Assessment during COVID-19. Journal of Hospitality, Leisure, Sport \& Tourism Education. https://doi.org/10.1016/j.jhls te.2021.100337. Retrieved from http://www.elsevier.com/locate/jhlste (accessed 15 July 2021).

Blo o m, B.S. Taxonomy of Educational Objectives (1956). Published by Allyn and Bacon, Boston, MA. Copyright (c) 1984 by Pearson Education.

Gulayev, V., Peremitko, V., Hlushchenko, O., Karavan, N., Solod, V., \& Dobryk, L. (Eds.) (2017). Polozhennya pro organizaciyu osvitn'ogo procesu v Dniprovs'komu derzhavnomu tekhnichnomu universiteti. [Regulations on the organization of the educational process at the Dniprovsky State Technical University]. Kamianske: Dniprovsky State Technical University. 
Iglesias-Pradas, S., Hernandez-García, A., Chaparro-Pelaez, J., \& Prieto, J.L. (2021). Emergency remote teaching and students' academic performance in higher education during the COVID-19 pandemic: A case study. Computers in Human Behavior, 119 (2021). https://doi.org/10.1016/j.chb.2021.106713. Retrieved from http://www.else vier.com/locate/comphumbeh (accessed 20 July 2021).

Information portal of Dniprovsky State Technical University. Retrieved from http://www. dstu.dp.ua/Portal/WWW/ (accessed 16 July 2021).

International Standard Classification of Education: Fields of education and training 2013 (ISCED-F 2013). ISBN 978-92-9189-150-4. Retrieved from http://uis.unesco.org/sites/ default/files/documents/isced-fields-of-education-and-training-2013-en.pdf (accessed 7 July 2021).

Kabinet Ministriv Ukraïni, Postanova pro zatverdzhennya Nacional'noï ramki kvalifikacij No. 1341 [Cabinet of Ministers of Ukraine, Resolution of the Cabinet of Ministers of Ukraine On approval of the National Qualifications Framework No. 1341]. Official Gazette of Ukraine 101, 15 (2012).

Karimov, G., Kuzmenko, N., \& Radchenko, T. (2020). Distance technologies in traditional model of higher education. In E. Smyrnova-Trybulska (Ed.). Innovative Educational Technologies, Tools and Methods for E-learning. E-learning Series. Vol. 12. KatowiceCieszyn: STUDIO NOA for University of Silesia (pp. 137-146). https://doi.org/10.34916/ el.2020.12.

Krathwohl, D.R., Bloom, B.S., \& Ma sia, B.B. (1964). Taxonomy of educational objectives: The classification of educational goals. Handbook II: the affective domain. New York: David McKay Company.

K r u p c ała, K. (2021). Developing e-business competencies among business students - research and opportunities. 25th International Conference on Knowledge-Based and Intelligent Information \& Engineering Systems. Procedia Computer Science 192 (2021) 47114720. https://doi.org/10.1016/j.procs.2021.09.249.

Ku cher, M., Vor on in a, A., \& Tar a s e n ko, S. (Eds.) (2019). Osvitn'o-profesijna programa za special'nistyu 073 „Menedzhment” galuzi znan’ 07 „Upravlinnya ta administruvannya" dlya pershogo (bakalavrs'kogo) rivnya vishchoï osviti. [Curriculum for the course 073 "Management" in the field of knowledge 07 "Management and Administration" for the first (bachelor's) level of higher education]. Kamianske: Dniprovsky State Technical University.

Loren za, L. \& Carter, D. (2021). Emergency online teaching during COVID-19: A case study of Australian tertiary students in teacher education and creative arts International Journal of Educational Research Open 2-2 (2021). https://doi.org/10.1016/j.ijedro.2021. 100057. Retrieved from www.elsevier.com/locate/ijedro (accessed 30 July 2021).

Metodichni rekomendaciï shchodo rozroblennya standartiv vishchoï osviti. Nakaz Ministerstva osviti i nauki Ukraïni No. 600 vid 01.06.2017. (u redakciï nakazu Ministerstva osviti i nauki Ukraïni vid 30.04.2020 r. No. 584). [Methodical recommendations for the development of higher education standards. Order of the Ministry of Education and Science of Ukraine No. dated 01.06.2017]. Retrieved from https://mon.gov.ua/ua/osvita/ visha-osvita/naukovo-metodichna-rada-ministerstva-osviti-i-nauki-ukrayini/metod ichni-rekomendaciyi-vo (accessed 19 June 2021). 
Polozhennya pro distancijne navchannya. Nakaz Ministerstva osviti i nauki Ukraïni No. 466 vid 25.04.2013. (zi zminami zgidno z nakazami Ministerstva osviti i nauki No. 660 vid 01.06.2013, No. 761 vid 14.07.2015). [Regulations on distance learning. Order of the Ministry of Education and Science of Ukraine No. 466 vid 25.04.2013]. Retrieved from https:// zakon.rada.gov.ua/laws/show/z0703-13 (accessed 17 June 2021).

Rekomendaciï ŝodo organizaciï potočnogo, semestrovogo kontrolju ta atestacłż zdobuvačiv fahovoï pered viŝoï ta viŝoï osviti iz zastosuvannjam distancijnih tehnologij navčannja. List Ministerstva osviti i nauki Ukraïni No. 1/9-249 vid 14.05.2020. Retrieved from https://mon.gov.ua/ua/npa/shodo-organizaciyi-potochnogo-semestrovogo-kontrolyu -ta-atestaciyi-zdobuvachiv-osviti-iz-zastosuvannyam-distancijnih-tehnologij (accessed 19 July 2021).

Szopinski, T., \& Bachnik, K. (2022). Student evaluation of online learning during the COVID-19 pandemic. Technological Forecasting \& Social Change, 174. https://doi.org/10.10 16/j.techfore.2021.121203. Retrieved from https://www.journals.elsevier.com/technologi cal-forecasting-and-social-change (accessed 19 August 2021).

Standart vishchoï osviti. Pershij (bakalavrs'kij) riven' vishchoï osviti. Stupin’ „bakalavr”. Galuz' znan': 07 „Upravlinnya ta administruvannya”, special'nist': 073 „Menedzhment”. Nakaz Ministerstva osviti i nauki Ukraïni No. 1165 vid 29.10.2018. (zi zminami zgidno z nakazom Ministerstva osviti i nauki No. 1338 vid 05.12.2018). [Standard of higher education. The first (bachelor's) level of higher education. Bachelor's degree. Field of knowledge: 07 "Management and Administration", specialty: 073 "Management". Order of the Ministry of Education and Science of Ukraine No. 1165 dated 29.10.2018]. Retrieved from https:// mon.gov.ua/storage/app/media/vishcha-osvita/zatverdzeni\%20standarty/12/21/073 -menedzhment-bakalavr.pdf (accessed 19 June 2021).

Tuning Educational Structures in Europe (2007). Introduction to Tuning-2. Retrieved from http://www.unideusto.org/tuningeu/images/stories/documents/General_Brochure_ final_version.pdf (accessed 1 July 2021).

Zakon Ukraïni „Pro viŝu osvitu” (vid 1 lipnja 2014 roku No. 1556-VII, Redakcija vid 16.07. 2021. Retrieved from http://zakon5.rada.gov.ua/laws/show/1556-18 (accessed 19 July 2021). 